\title{
Naturally Presented MHC Ligands Carrying Glycans
}

\author{
Jörn Dengjela Stefan Stevanovićb \\ a Immatics Biotechnologies $\mathrm{GmbH}$, \\ ${ }^{b}$ Abteilung Immunologie, Interfakultäres Institut für Zellbiologie, Eberhard-Karls-Universität Tübingen, Germany
}

\section{Key Words}

HLA - Glycopeptide · Immunotherapy - Autoimmunity · Cancer

\section{Summary \\ Glycosylation is the most common and most diverse posttranslational modification of proteins. During tu- morigenesis altered glycosylation patterns are a hall- mark. In addition, changes in glycosylation are important in autoimmune diseases, such as rheumatoid arthritis. $\mathrm{MHC}$ class I- as well as MHC class II-presented glycopep- tides have been described, and both CD8+ and CD4+ T cells are able to recognize glycopeptides in a classical MHC-restricted way. Different glycosylation patterns may influence $T$ cell responses during disease, creating neoepitopes or blocking existing $T$ cell responses to un- modified peptides by changing epitopes or abolishing binding to $\mathrm{MHC}$ molecules. In the present review, we dis- cuss the current knowledge of glycosylated MHC class I and II peptides - which peptides have been described, and what is their impact on cellular immunity.}

\section{MHC Peptide Complexes}

The immune system is able to distinguish between self and non-self through humoral and cellular defense mechanisms, respectively. B cell receptors and antibodies (Ab) bind 3-dimensional molecular structures of a large variety, among them proteins, lipids and carbohydrates, in their native or denatured form. T cells, on the other hand, are more limited. Via their $\mathrm{T}$ cell receptor (TCR), they recognize parts of processed pro-

\section{Schlüsselwörter}

HLA · Glykopeptid · Immuntherapie · Autoimmunität · Krebs

\section{Zusammenfassung}

Glykosylierung ist die häufigste und facettenreichste posttranslationale Proteinmodifizierung. Während der Tumorentwicklung und bei Autoimmunerkrankungen, z.B. bei rheumatoider Arthritis, treten veränderte Glykosylierungsmuster auf. MHC-Klasse-I- und -Klasse-II-präsentierte Glykopeptide sind bekannt, und sowohl CD8+ als auch CD4+ T-Zellen sind in der Lage, Glykopeptide MHC-restringiert zu erkennen. Bei krankhaften Veränderungen können unterschiedliche Glykosylierungsmuster T-Zell-Reaktionen beeinflussen, indem sie Neoepitope hervorbringen oder existierende T-Zell-Reaktionen gegen unmodifizierte Peptide blockieren beziehungsweise die MHC-Bindung verhindern. In diesem Review diskutieren wir das gegenwärtige Wissen über MHC-Klasse-I- und -Klasse-II-präsentierte Glykopeptide und beschreiben, welche Peptide bekannt sind und welchen Einfluss sie auf die zelluläre Immunität haben.

teins, peptides which have to be presented on special receptors, the major histocompatibility complex (MHC) molecules, on the cell surface. The 2 major subsets of T cells, CD8+ and CD4+ T cells, recognize 2 different types of MHC molecules, MHC class I and MHC class II. In the classical view, MHC class I molecules present peptides from endogenously synthesized proteins on the surface of the vast majority of cells, allowing circulating CD8+ cytotoxic T lymphocytes (CTL) to survey cells for possible infections or improper protein ex-

\begin{tabular}{ll}
\hline KARGER & @ 2006 S. Karger GmbH, Freiburg \\
$\begin{array}{l}\text { Fax +4976145207 14 } \\
\begin{array}{l}\text { E-mail Information@Karger.de } \\
\text { www.karger.com }\end{array}\end{array}$ & Accessible online at: \\
www.karger.com/tmh
\end{tabular}

Dr. Stefan Stevanović

Abteilung Immunologie, Interfakultäres Institut für Zellbiologie

Eberhard-Karls-Universität Tübingen

Auf der Morgenstelle 15, 72076 Tübingen, Germany

Tel. +49 7071 29-87645, Fax -5653

E-mail stefan.stevanovic@uni-tuebingen.de 
Fig. 1. Asparagine linked oligosaccharides. A Pentasaccharide core structure common to all

$\mathrm{N}$-linked oligosaccharides. B Structures of the major types of $\mathrm{N}$-linked oligosaccharides.

$\mathrm{Gal}=$ galactose, GlcNAc $=$ N-acetylglucosamine,

Fuc $=$ fucose,

Man = mannose, S.A.

$=$ sialic acid.
A

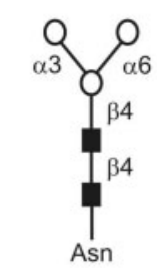

Pentasaccharide Core

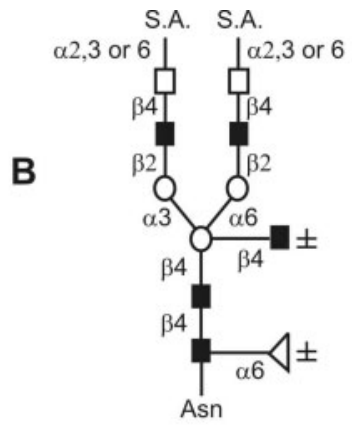

Complex

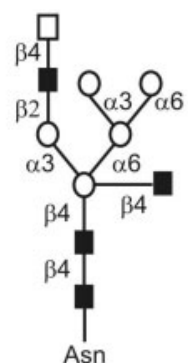

Hybrid

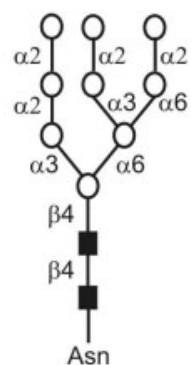

High Mannose

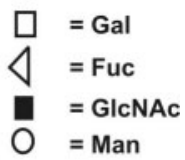

= Man pression, such as might be seen during tumorigenesis. As MHC class I genes are highly polymorphic, proteins encoded by each allele will bind only a unique set of peptides. Anchor residues of antigenic peptides determine the binding specificity to the peptide binding groove of a specific MHC molecule [1]. MHC class I molecules define the position of anchor residues which have to be occupied by specific amino acids. Most common, peptides of 8-10 amino acids in length are generated by normal cellular degradation of proteins and presented on the cell surface by MHC class I [2]. The ubiquitin-proteasome system generates precursor peptides that have the correct $\mathrm{C}$-terminus but may have $\mathrm{N}$-terminal extensions of several amino acids [3].

MHC class II molecules typically present peptides from exogenous proteins acquired by endocytosis or from internalized plasma membrane proteins to CD4+ helper T (Th) cells. MHC class II peptides are generated in lysosomes and are loaded onto MHC class II molecules in special compartments - the MHC class II containing compartment (MIIC) [4]. Compared to MHC I molecules, the binding grooves of MHC II molecules are open at the end. Therefore, MHC II ligands show a much greater variety in length, in general being 11 to more than 20 amino acids long [5, 6]. Often, MHC II peptides encompass a core sequence which is variably extended at both termini [7]. In contrast to MHC I molecules, binding of class II molecules and their ligands is mainly based on interactions between peptide backbone and the MHC II binding groove [8]. MHC II molecules have also binding pockets specific for defined anchor amino acids, but compared to MHC class I they appear degenerated.

It has been shown in numerous publications that class I as well as class II peptides may contain posttranslational modifications, such as deamidation $[9,10]$, cysteinylation [11, 12], glycosylation [13] and phosphorylation [14], and that these modifications may be important for $\mathrm{T}$ cell recognition. In this review, we will discuss the current knowledge of glycosylated MHC class I and class II peptides - which peptides have been described, how have they been identified, and what is their impact on cellular immunity.

\section{Glycoproteins}

Glycosylation is the most common posttranslational modification of proteins. In higher organisms, all surface proteins and the majority of secreted proteins are glycosylated. It is also the most diverse modification, both with respect to the modified amino acids and the attached structure [15]. Mammalian glycoproteins commonly contain 3 types of constitutive glycans: N-linked glycans which are bound to asparagine side chains, O-linked glycans bound to serine and threonine side chains, and the carbohydrate components of glycosylphosphatidylinositol (GPI) anchors. N-linked glycans are attached via an $\mathrm{N}$-acetylglucosamine residue (GlcNAc) to an asparagine residue contained within an Asn-X-(Ser, Thr) consensus motif where $\mathrm{X}$ can be any amino acid except proline. $\mathrm{N}$-linked glycosylation to Asn-X-Cys has also been observed [16]. N-linked glycans all share a common pentasaccharide core structure but differ in their outer branches [17]. Examples of common N-linked oligosaccharides are shown in figure 1. O-linked glycans are much more diverse. Modifications range from monosaccharides to large polysaccharides with no common core structure and no consensus amino acid sequence at the attachment point. Typically, O-linked glycans are attached via a $\mathrm{N}$-acetylgalactosamine residue (GalNAc) to a serine or threonine residue [18] without a clear consensus motif [19]. GPI anchors are glycolipids attached to the carboxy terminus of proteins in order to anchor those proteins to membranes. A tetrasaccharide core is attached via a phosphoethanolamine to the carboxy terminus. The whole structure is anchored via a phosphatidylinositol to the membrane. The linear tetrasaccharide may have a variety of attached sugar residues, depending on the source of the anchor [20]. Besides the common glycanprotein linkages, numerous special sugar-protein bonds exist, for example O-linked glucose residues (Glc) attached to tyrosine side chains in glycogenin, the primer of glycogen synthesis [21], or glycans O-linked to hydoxylysine residues in type II collagen [22]. Complex N- and O-linked glycosylation occurs in the endoplasmic reticulum (ER) and the Golgi apparatus on secreted or membrane proteins. In contrast, nucleocyto- 
Table 1. MHC presented glycopeptides ${ }^{\mathrm{a}}$

\begin{tabular}{|c|c|c|c|c|c|}
\hline $\begin{array}{l}\text { Entrez } \\
\text { gene ID }\end{array}$ & Gene symbol & Peptide sequence & Sugar & MHC molecule & $\begin{array}{l}\text { Refe- } \\
\text { rence }\end{array}$ \\
\hline 962 & CD48 & DPQSGALYISKVQKEDNSTYI $^{\mathrm{b}}$ & $\operatorname{GlcNAc}(\beta)-$ & HLA-DRB1*0801 & [39] \\
\hline 962 & CD48 & GALYISKVQKEDNSTYI ${ }^{\mathrm{b}}$ & $\operatorname{GlcNAc}(\beta)-$ & HLA-DRB1*0801 & [39] \\
\hline 3117 & HLA-DQA1 & IVIKRSNSTAATN $^{\mathrm{b}}$ & $\operatorname{GlcNAc}(\beta 4)-\operatorname{GlcNAc}(\beta)-$ & $\begin{array}{l}\text { HLA-DQA1*0301/ } \\
\text { DQB } 1 * 0302\end{array}$ & [40] \\
\hline 963 & CD53 & SIHRYHSDNSTKAASWD ${ }^{\mathrm{b}}$ & $\begin{array}{l}\operatorname{Man}(\alpha 6) \quad \operatorname{Fuc}(\alpha 6) \\
\operatorname{Man}(\beta 4)-\operatorname{GlcNAc}(\beta 4)-\operatorname{GlcNAc}(\beta)- \\
\operatorname{Man}(\alpha 3)\end{array}$ & HLA-DRB1*0401/DRB4*0101 & {$[41]$} \\
\hline 963 & CD53 & IHRYHSDNSTKAAWD $^{\mathrm{b}}$ & $\begin{array}{l}\operatorname{Man}(\alpha 6) \quad \operatorname{Fuc}(\alpha 6) \\
\operatorname{Man}(\beta 4)-\operatorname{GlcNAc}(\beta 4)-\operatorname{GlcNAc}(\beta)- \\
\operatorname{Man}(\alpha 3)\end{array}$ & HLA-DRB1*0401/DRB4*0101 & {$[41]$} \\
\hline 25412 & COL2A1 (rat) & GEPGIAGFKGEQGPK $^{\mathrm{c}}$ & $\operatorname{Gal}(\beta)-$ or $\operatorname{Glc}(\beta 2)-\operatorname{Gal}(\beta)-$ & $\mathrm{H} 2-\mathrm{A}^{\mathrm{q}}$ & {$[54]$} \\
\hline 1280 & $\begin{array}{l}\text { COL2A1 } \\
\text { (human) }\end{array}$ & GIAGFKGEQGPKGEPGPAGP & $\operatorname{Gal}(\beta)-$ & HLA-DRB1*0401 & [49] \\
\hline 4582 & MUC1 & AHGVTSAPDTRPAPGSTAPPA $^{\mathrm{c}}$ & $\operatorname{Gal}(\beta 3)$-GalNAc( $\alpha)$ - & $\mathrm{H} 2-\mathrm{A}^{\mathrm{b}}$ & [42] \\
\hline 4582 & MUC1 & SAPDTRPA $^{c}$ & GalNAc- & $\mathrm{H} 2-\mathrm{K}^{\mathrm{b}}$ & {$[38]$} \\
\hline
\end{tabular}

aShown are sequences of identified glycopeptides, sugar attachment sites (bold), attached sugars and presenting MHC molecules.

${ }^{b}$ Naturally presented peptides identified by MS.

'Presented T cell epitopes.

plasmic proteins carry only a simple monosaccharide modification. Serine and threonine residues are modified by single O-linked GlcNAc residues which most likely play a role in signal transduction [23].

\section{MHC Glycopeptide-TCR Interactions}

By the late 1980s/early 1990s, evidence grew stronger that $\mathrm{T}$ cell reactions against glycoproteins might be influenced by attached sugar moieties [24, 25]. The first detailed studies on MHC glycopeptide-TCR interactions followed soon after. Synthetic peptides modified by carbohydrate bearing amino acids were used to study MHC class II binding and the ability to elicit $\mathrm{T}$ cell responses. It could be shown that a single GlcNAc residue bound to anchor amino acids abrogated class II binding [26]. However, mono- and disaccharides attached to non-anchor amino acids within or outside the MHC-TCR contact region allowed glycopeptide MHC class II binding and influenced $\mathrm{T}$ cell recognition. Carbohydrates bound to amino acids outside the MHC-TCR contact region were able to change $\mathrm{T}$ cell recognition by conformational influences on the peptide backbone [27]. Carbohydrates bound within the contact region could elicit $\mathrm{T}$ cell responses specific for either only the attached sugar moiety [26] or for both the carbohydrate and the peptide [28]. Experiments with glycopeptide analogues demonstrated that structural changes in carbohydrates as well as in peptides may result in a diminished or abrogated $\mathrm{T}$ cell recognition. This could be linked to a partial or absent phosphorylation of TCR zeta chains [29]. Analysis of TCR fine specificity yielded that carbohydrates attached to amino acids pointing towards TCR were more important for TCR recognition than carbohydrates pointing away from TCR. In addition, it was shown that $\mathrm{T}$ cells could discriminate between the position of a single hydroxyl group indicating that $\mathrm{T}$ cell recognition can be very strict $[30,31]$. TCR sequencing demonstrated that $\mathrm{V} \alpha$ gene usage was more diverse than $\mathrm{V} \beta$ gene usage and that CDR3 sequences were highly diverse, containing mainly small polar amino acids as observed in lectins. These small polar amino acids might be responsible for H-bonding with glycans. Thus, the glycan recognizing TCR repertoire seems to be quite large [32].

In 1994, Haurum and colleagues [33] showed for the first time that glycopeptides could bind to MHC class I molecules and be presented to $\mathrm{T}$ cells. They were able to rise a CTL line against a glycopeptide homologue of sendai virus nucleoprotein 324-332 (GeneID: 1489779) modified with a single GlcNAc residue at position 327 within the TCR contact region. Recognition of the peptide was strictly carbohydrate dependent. In another example the same group was able to show that the glycosylated form of a peptide could bind to a MHC molecule, while the unglycosylated peptide failed to do so [34]. Crystal structures of $\mathrm{H} 2-\mathrm{K}^{\mathrm{b}}[35]$ and $\mathrm{H} 2-\mathrm{D}^{\mathrm{b}}[36]$ carrying different glycopeptides demonstrated that sugar residues attached at TCR contact sites were solvent exposed and able to interact with TCRs. Further, molecular modeling showed that single carbohydrate rings fit perfectly between 2 CDR3 loops of $\alpha \beta$ TCRs [36]. Regarding the structure of $\alpha \beta$ and $\gamma \delta$ TCRs, it seems likely that mono- and disaccharides induce $\alpha \beta \mathrm{T}$ cells in a MHC-dependent fashion, whereas longer saccharides induce $\gamma \delta$ T cells MHC independently [35, 37].

In general, glycosylation of anchor amino acids abrogates MHC binding [26]. However, in the case of the MUC1 peptide SAPDTRPA, it could be shown that a GalNAc residue at- 
tached to position 5 acts as an anchor residue and increases binding to $\mathrm{H} 2-\mathrm{K}^{\mathrm{b}}$ molecules dramatically (table 1 ) [38]. T cells generated against the modified peptide cross-reacted with the unmodified peptide indicating that the sugar moiety was buried within the MHC binding groove.

\section{Glycosylated MHC Class II Peptides}

MHC presented glycopeptides can be identified by 2 different approaches. It is possible to isolate peptides from presenting cells and analyze them by mass spectrometry (MS). This approach yields the exact structure of the presented glycopeptide. As peptides and carbohydrates behave very differently during MS analysis, it is difficult to elucidate simultaneously the structure of the peptide as well as of the attached carbohydrate [39-41]. A second approach is the screening of T cells with glycopeptide libraries. This approach is very laborious compared to the MS based one, and it still has to be verified that the glycopeptides are also presented by cells [42]. In addition, cellular glycopeptides do not necessarily have exactly the same structures as their synthetic counterparts.

Since the early 1990s, it has been demonstrated by different examples that naturally MHC class II presented peptides can be modified by carbohydrates (table 1). It has become clear that even complex glycans may not be degraded during class II peptide generation in the MIIC and, thus, be presented on MHC class II molecules at the cell surface [41, 42].

That glycopeptide specific $\alpha \beta$ CD4+ T cells play an important role in vivo became evident after the characterization of $\mathrm{T}$ cell clones specific to the bee venom allergen phospholipase A2 isolated from allergic patients [43]. HLA-DR restricted T cells failed to respond to $\alpha$-mannosidase-treated phospholipase A2, indicating that complex carbohydrates may be responsible for $\mathrm{T}$ cell recognition. However, as the exact structure of the immunogenic glycopeptide could not be elucidated, it remained unclear if the carbohydrate took part in MHC-TCR interaction.

\section{Glycosylated MHC Class I Peptides}

In general, MHC class I presented peptides are transported via the transporter associated with antigen processing (TAP) into the ER where they are loaded on MHC class I molecules [44]. It could be shown that TAP is able to transport O-linked GlcNAc bearing peptides into the ER and that approximately $0.1 \%$ of naturally presented class I peptides contain sugars, the majority of them single GlcNAc residues [13]. Peptides carrying N-linked GlcNAc residues are probably not presented by MHC class I [45]. The presentation of glycopeptides on MHC class I molecules may be dependent on the peptide motif of the corresponding MHC allele. It seems possible that some alleles, such as HLA-B*2705, have a binding motif that does not allow glycopeptide binding [46].

Naturally Presented MHC Ligands Carrying Glycans
Glycoproteins may not only influence $\mathrm{T}$ cell recognition by presentation of corresponding glycopeptides on MHC molecules. In several examples, epitopes of deglycosylated peptides from viral as well as tumor associated antigens which were originally $\mathrm{N}$-glycosylated could be identified [9, 45, 47]. Through the action of cytosolic N-glycoamidase, N-glycosylated peptides become deglycosylated, changing the sugar-bearing asparagine residue into a free aspartic acid residue [48]. Thus, glycosylation followed by deglycosylation may yield antigenic peptides different from the genetically encoded amino acid sequence.

\section{Glycopeptides in Autoimmunity}

Rheumatoid arthritis (RA) is a severe inflammatory autoimmune disease affecting peripheral joints and causing cartilage destruction. Activated CD4+ T cells play a critical role during the disease which is associated with HLA-DRB1*0101 and HLA-DRB1*0401 [49]. Type II collagen induced arthritis (CIA) is a widely used animal model for RA [50, 51]. T cell recognition of type II collagen (CII, gene symbol: COL2A1) is believed to play a crucial role in the induction and development of arthritis $[52,53]$. CII is posttranslationally modified by hydroxylation of proline and lysine residues which have to be in an appropriate position (G-X-P/G-X-K). Hydroxylated lysine residues can also be glycosylated by monosaccharides (galactose, Gal) or by disaccharides (glucosyl-galactose, Glc-Gal). It was shown in several studies that CII peptide GEPGIAGFKGEQGPK (table 1) is an immunodominant $\mathrm{T}$ cell epitope and that the glycosylation state of the peptide has a strong impact on the severity of $\mathrm{T}$ cell responses $[22,54,55]$. In HLA-DRB1*0401, human CD4 and human $\mathrm{CII}$ transgenic mice, $\mathrm{T}$ cell responses against $\mathrm{CII}$ peptide GIAGFKGEQGPKGEPGPAGP modified with Gal residues at position 6 and/or 12 (table 1) could be detected in in vitro stimulations after immunization with human CII. Ex vivo analysis of RA patients demonstrated a similar T cell reactivity as observed in mice [49]. In normal human cartilage CII seems to be completely glycosylated at position 264 with Gal and Glc-Gal residues. However, in arthritic cartilage, glycosylated and unglycosylated forms of the protein are present [56]. As the corresponding glycosylated peptide seems to be the immunodominant $\mathrm{T}$ cell epitope in RA, it might be possible that attacked chondrocytes switch from glycosylated CII synthesis during an arthritic attack to non-glycosylated CII synthesis. Regarding possible therapy strategies, T cell depletion via TCR engagement may not be feasible, as glycopeptide specific T cells display a broad TCR repertoire [55]

\section{Glycopeptides in Cancer}

Altered glycosylation patterns are a hallmark during tumorigenesis [57]. Changes in glycosylation may include both, 
under- and overexpression of naturally occurring glycans, as well as neoexpression of glycans [58]. Two examples of cancer related carbohydrate antigens are the Thomsen-Freidenreich antigen ( $\mathrm{T}$ or TF antigen, Gal-GalNAc- $O$-Ser) and its immediate precursor the Tn antigen (GalNAc- $O$-Ser) [59]. They are expressed on a variety of epithelial tumors and generally not found on normal tissue [60]. Both are highly immunogenic, evoking humoral immune responses [61]. Using synthetic glycopeptides it was shown that CD4+ T cells are also able to recognize these sugars [62].

The mucin-like glycoprotein MUC1 is a tumor associated antigen expressed in a variety of carcinomas. In normal cells, MUC1 is heavily glycosylated by branched O-linked glycans [63]. However, in tumor cells, MUC1 glycosylation is prematurely terminated yielding short carbohydrate precursors, such as the described $\mathrm{T}$ and $\mathrm{Tn}$ saccharides [64]. It was demonstrated that MUC1 was processed by dendritic cells (DCs) without being deglycosylated, and corresponding glycopeptides were presented on cell surfaces. In addition, CD4+ T cells were able to recognize naturally glycosylated tumor derived MUC1 on DCs (table 1) [42]. In one example, altered MUC1 glycopeptide ligands were highly immunogenic [65]. An immunogenic MUC1-derived class I peptide could also be identified. However, in this case, the sugar residue was used as an anchor residue being buried within the MHC binding groove. Therefore, peptide recognition was sugar independent (table 1) [38]. Interestingly, a CD8 $+\mathrm{T}$ cell epitope derived from the melanoma specific tumor antigen tyrosinase and containing a N-linked glycosylation motif, is recognized in 2 isoforms, YMNGTMSQV and YMDGTMSQV, both of which appear to be naturally presented by the human MHC class I molecule HLA-A*0201 [9]. Deglycosylated tumor associated antigens may yield antigenic peptides which are not genetically encoded, thus further increasing the number of potential $\mathrm{T}$ cell epitopes. It even seems possible to elicit CTL responses against tumor associated glycolipids, such as ganglioside $\mathrm{G}_{\mathrm{D} 2}$. How this glycolipid is presented by MHC molecules and if peptides are also involved remains still to be elucidated [66].

\section{Conclusion}

In higher organisms, all surface proteins and the majority of secreted proteins are glycosylated. Glycosylation is the most common and most diverse posttranslational modification of proteins [15]. Almost all key molecules of the innate as well as the adaptive immune system are glycoproteins [67]. In addition, it is well known that altered glycosylation patterns are characteristic during tumorigenesis [59] and may also be important during autoimmune diseases, such as RA [68]. Therefore, it is not surprising that both CD8+ and CD4+ T cells can recognize glycopeptides in a classical MHC restricted way. Different glycosylation patterns may influence T cell responses in different ways. They may lead to neoepitopes or block existing $\mathrm{T}$ cell responses to unmodified peptides by changing epitopes or abolishing binding to MHC molecules [26, 28]. It is well established that glycopeptides are presented by MHC class I and II molecules in vivo [13, 39-41]. However, sequence information of naturally presented MHC glycopeptides regarding the peptide and corresponding sugar moiety is rather limited. This may reflect the fact that glycopeptides are difficult to identify by MS analysis, as peptide and sugar moieties behave very differently during collision induced dissociation in tandem MS experiments. In addition, glycopeptides are not commonly used in $\mathrm{T}$ cell screening experiments, as they are more difficult to synthesize.

Regarding the ubiquity of glycosylation and the fact that MHC molecules are able to present glycopeptides to T cells, it is very likely that glycosylated $\mathrm{T}$ cell epitopes could be important during autoimmune diseases and in anti-cancer immunotherapy. First evidence has been collected, however too few MHC glycopeptides have been identified so far. The specific search for MHC presented glycopeptides, for example with the help of new sensitive mass spectrometers which allow $\mathrm{MS}^{3}$ scans routinely, should be able to shed more light onto this challenging research area.

\section{References}

1 Falk K, Rötzschke O, Stevanovic S, Jung G, Rammensee HG: Allele-specific motifs revealed by sequencing of self-peptides eluted from MHC molecules. Nature 1991;351:290-296.

2 York IA, Goldberg AL, Mo XY, Rock KL: Proteolysis and class I major histocompatibility complex antigen presentation. Immunol Rev 1999;172: 49-66.

3 Kloetzel PM: Generation of major histocompatibility complex class I antigens: functional interplay between proteasomes and TPPII. Nat Immunol 2004;5:661-669.

4 Neefjes J: CIIV, MIIC and other compartments for MHC class II loading. Eur J Immunol 1999;29: 1421-1425.
5 Brown JH, Jardetzky TS, Gorga JC, Stern LJ, Urban RG, Strominger JL, Wiley DC: Threedimensional structure of the human class II histocompatibility antigen HLA-DR1. Nature 1993;364: 33-39.

6 Rammensee HG, Bachmann J, Stevanovic S: MHC Ligands and Peptide Motifs. Heidelberg, Springer, 1997.

7 Engelhard VH: Structure of peptides associated with class I and class II MHC molecules. Annu Rev Immunol 1994;12:181-207.

8 Stern LJ, Brown JH, Jardetzky TS, Gorga JC, Urban RG, Strominger JL, Wiley DC: Crystal structure of the human class II MHC protein HLADR1 complexed with an influenza virus peptide. Nature 1994;368:215-221.
9 Skipper JC, Hendrickson RC, Gulden PH, Brichard V, Van Pel A, Chen Y, Shabanowitz J, Wolfel T, Slingluff CL Jr, Boon T, Hunt DF, Engelhard VH: An HLA-A2-restricted tyrosinase antigen on melanoma cells results from posttranslational modification and suggests a novel pathway for processing of membrane proteins. J Exp Med 1996; 183:527-534.

10 Schmid DG, der Mulbe FD, Fleckenstein B, Weinschenk T, Jung G: Broadband detection electrospray ionization Fourier transform ion cyclotron resonance mass spectrometry to reveal enzymatically and chemically induced deamidation reactions within peptides. Anal Chem 2001;73:6008-6013. 
11 Meadows L, Wang W, den Haan JM, Blokland E, Reinhardus C, Drijfhout JW, Shabanowitz J, Pierce R, Agulnik AI, Bishop CE, Hunt DF, Goulmy E, Engelhard VH: The HLA-A*0201-restricted H-Y antigen contains a posttranslationally modified cysteine that significantly affects $\mathrm{T}$ cell recognition. Immunity 1997;6:273-281.

12 Pierce RA, Field ED, den Haan JM, Caldwell JA, White FM, Marto JA, Wang W, Frost LM, Blokland E, Reinhardus C, Shabanowitz J, Hunt DF, Goulmy E, Engelhard VH: Cutting edge: the HLA-A*0101restricted HY minor histocompatibility antigen originates from DFFRY and contains a cysteinylated cysteine residue as identified by a novel mass spectrometric technique. J Immunol 1999;163: 6360-6364.

13 Haurum JS, Hoier IB, Arsequell G, Neisig A, Valencia G, Zeuthen J, Neefjes J, Elliott T: Presentation of cytosolic glycosylated peptides by human class I major histocompatibility complex molecules in vivo. J Exp Med 1999;190:145-150.

14 Zarling AL, Ficarro SB, White FM, Shabanowitz J, Hunt DF, Engelhard VH: Phosphorylated peptides are naturally processed and presented by major histocompatibility complex class I molecules in vivo. J Exp Med 2000;192:1755-1762.

15 Lis H, Sharon N: Protein glycosylation. Structural and functional aspects. Eur J Biochem 1993;218: $1-27$.

16 Vance BA, Wu W, Ribaudo RK, Segal DM, Kearse KP: Multiple dimeric forms of human CD69 result from differential addition of $\mathrm{N}$-glycans to typical (Asn-X-Ser/Thr) and atypical (Asn-X-cys) glycosylation motifs. J Biol Chem 1997;272:23117-23122.

17 Kornfeld R, Kornfeld S: Assembly of asparaginelinked oligosaccharides. Annu Rev Biochem 1985; 54:631-664

18 Varki A, Cummings R, Esko J, Freeze H, Hart G, Marth J: Essentials of Glycobiology. Cold Spring Harbor, Cold Spring Harbor Laboratory Press, 1999.

19 Van den Steen PE, Rudd PM, Wormald MR, Dwek RA, Opdenakker G: O-linked Glycosylation in Focus. Trends in Glycoscience and Glycotechnology 2000;12:35-49.

20 Ferguson MA: Colworth Medal Lecture. Glycosylphosphatidylinositol membrane anchors: the tale of a tail. Biochem Soc Trans 1992;20:243-256.

21 Smythe C, Caudwell FB, Ferguson M, Cohen P: Isolation and structural analysis of a peptide containing the novel tyrosyl-glucose linkage in glycogenin. EMBO J 1988;7:2681-2686

22 Corthay A, Backlund J, Holmdahl R: Role of glycopeptide-specific $\mathrm{T}$ cells in collagen-induced arthritis: an example how post-translational modification of proteins may be involved in autoimmune disease. Ann Med 2001;33:456-465.

23 Wells L, Vosseller K, Hart GW: Glycosylation of nucleocytoplasmic proteins: signal transduction and O-GlcNAc. Science 2001;291:2376-2378.

24 Katsuki M, Kakimoto K, Kawata S, Kotani S, Koga $\mathrm{T}$ : Induction of delayed-type hypersensitivity by the $\mathrm{T}$ cell line specific to bacterial peptidoglycans. J Immunol 1987;139:3570-3572.

-25 Singhal A, Fohn M, Hakomori S: Induction of alpha-N-acetylgalactosamine-O-serine/threonine (Tn) antigen-mediated cellular immune response for active immunotherapy in mice. Cancer Res 1991:51:1406-1411.

26 Ishioka GY, Lamont AG, Thomson D, Bulbow N, Gaeta FC, Sette A, Grey HM: MHC interaction and $\mathrm{T}$ cell recognition of carbohydrates and glycopeptides. J Immunol 1992;148:2446-2451. 27 Harding CV, Kihlberg J, Elofsson M, Magnusson G,
Unanue ER: Glycopeptides bind MHC molecules and elicit specific T cell responses. J Immunol 1993; 151:2419-2425.

28 Deck B, Elofsson M, Kihlberg J, Unanue ER: Specificity of glycopeptide-specific T cells. J Immunol 1995;155:1074-1078.

29 Jensen T, Nielsen M, Gad M, Hansen P, Komba S, Meldal M, Odum N, Werdelin O: Radically altered $\mathrm{T}$ cell receptor signaling in glycopeptide-specific $\mathrm{T}$ cell hybridoma induced by antigen with minimal differences in the glycan group. Eur J Immunol 2001;31:3197-3206.

30 Jensen T, Hansen P, Galli-Stampino L, Mouritsen S, Frische K, Meinjohanns E, Meldal M, Werdelin $\mathrm{O}$ : Carbohydrate and peptide specificity of MHC class II-restricted $\mathrm{T}$ cell hybridomas raised against an O-glycosylated self peptide. J Immunol 1997; 158:3769-3778

31 Deck MB, Sjolin P, Unanue ER, Kihlberg J: MHCrestricted, glycopeptide-specific $\mathrm{T}$ cells show specificity for both carbohydrate and peptide residues. J Immunol 1999;162:4740-4744.

32 Jensen T, Hansen P, Faurskov NA, Meldal M, Komba S, Werdelin O: Shared structural motifs in TCR of glycopeptide-recognizing T cell hybridomas. Eur J Immunol 1999;29:2759-2768.

33 Haurum JS, Arsequell G, Lellouch AC, Wong SY, Dwek RA, McMichael AJ, Elliott T: Recognition of carbohydrate by major histocompatibility complex class I-restricted, glycopeptide-specific cytotoxic T lymphocytes. J Exp Med 1994;180:739-744.

34 Haurum JS, Tan L, Arsequell G, Frodsham P, Lellouch AC, Moss PA, Dwek RA, McMichael AJ, Elliott T: Peptide anchor residue glycosylation: effect on class I major histocompatibility complex binding and cytotoxic T lymphocyte recognition. Eur J Immunol 1995;25:3270-3276.

35 Speir JA, Abdel-Motal UM, Jondal M, Wilson IA: Crystal structure of an MHC class I presented glycopeptide that generates carbohydrate-specific CTL. Immunity 1999;10:51-61.

36 Glithero A, Tormo J, Haurum JS, Arsequell G, Valencia G, Edwards J, Springer S, Townsend A, Pao YL, Wormald M, Dwek RA, Jones EY, Elliott T: Crystal structures of two H-2Db/glycopeptide complexes suggest a molecular basis for CTL crossreactivity. Immunity 1999;10:63-74.

37 Abdel-Motal UM, Berg L, Rosen A, Bengtsson M, Thorpe CJ, Kihlberg J, Dahmen J, Magnusson G, Karlsson KA, Jondal M: Immunization with glycosylated Kb-binding peptides generates carbohydrate-specific, unrestricted cytotoxic T cells. Eur J Immunol 1996;26:544-551.

38 Apostolopoulos V, Yuriev E, Ramsland PA, Halton J, Osinski C, Li W, Plebanski M, Paulsen H, McKenzie IF: A glycopeptide in complex with MHC class I uses the GalNAc residue as an anchor. Proc Natl Acad Sci U S A 2003;100:15029-15034.

39 Chicz RM, Urban RG, Gorga JC, Vignali DA, Lane WS, Strominger JL: Specificity and promiscuity among naturally processed peptides bound to HLA-DR alleles. J Exp Med 1993;178:27-47.

40 Chicz RM, Lane WS, Robinson RA, Trucco M, Strominger JL, Gorga JC: Self-peptides bound to the type I diabetes associated class II MHC molecules HLA-DQ1 and HLA-DQ8. Int Immunol 1994;6:1639-1649.

41 Dengjel J, Rammensee HG, Stevanovic S: Glycan side chains on naturally presented MHC class II ligands. J Mass Spectrom 2005;40:100-104.
42 Vlad AM, Muller S, Cudic M, Paulsen H, Otvos L Jr, Hanisch FG, Finn OJ: Complex carbohydrates are not removed during processing of glycoproteins by dendritic cells: processing of tumor antigen MUC1 glycopeptides for presentation to major histocompatibility complex class II-restricted T cells. J Exp Med 2002;196:1435-1446.

43 Dudler T, Altmann F, Carballido JM, Blaser K: Carbohydrate-dependent, HLA class II-restricted, human $\mathrm{T}$ cell response to the bee venom allergen phospholipase A2 in allergic patients. Eur J Immunol 1995;25:538-542.

44 Lankat-Buttgereit B, Tampe R: The transporter associated with antigen processing: function and implications in human diseases. Physiol Rev 2002;82: 187-204.

45 Hudrisier D, Riond J, Mazarguil H, Oldstone MB, Gairin JE: Genetically encoded and post-translationally modified forms of a major histocompatibility complex class I-restricted antigen bearing a glycosylation motif are independently processed and co-presented to cytotoxic T lymphocytes. J Biol Chem 1999;274:36274-36280.

46 Kastrup IB, Stevanovic S, Arsequell G, Valencia G, Zeuthen J, Rammensee HG, Elliott T, Haurum JS Lectin purified human class I MHC-derived peptides: evidence for presentation of glycopeptides in vivo. Tissue Antigens 2000;56:129-135.

47 Selby M, Erickson A, Dong C, Cooper S, Parham P, Houghton M, Walker CM: Hepatitis C virus envelope glycoprotein $\mathrm{E} 1$ originates in the endoplasmic reticulum and requires cytoplasmic processing for presentation by class I MHC molecules. J Immunol 1999;162:669-676.

48 Suzuki T, Park H, Kitajima K, Lennarz WJ: Peptides glycosylated in the endoplasmic reticulum of yeast are subsequently deglycosylated by a soluble peptide: N-glycanase activity. J Biol Chem 1998; 273:21526-21530.

49 Bäcklund J, Carlsen S, Hoger T, Holm B, Fugger L, Kihlberg J, Burkhardt H, Holmdahl R: Predominant selection of $\mathrm{T}$ cells specific for the glycosylated collagen type II epitope (263-270) in humanized transgenic mice and in rheumatoid arthritis. Proc Natl Acad Sci U S A 2002;99:9960-9965.

50 Wooley PH, Luthra HS, Stuart JM, David CS: Type II collagen-induced arthritis in mice. I. Major histocompatibility complex (I region) linkage and antibody correlates. J Exp Med 1981;154:688-700.

51 Holmdahl R, Andersson M, Goldschmidt TJ, Gustafsson K, Jansson L, Mo JA: Type II collagen autoimmunity in animals and provocations leading to arthritis. Immunol Rev 1990;118:193-232.

52 Ranges GE, Sriram S, Cooper SM: Prevention of type II collagen-induced arthritis by in vivo treatment with anti-L3T4. J Exp Med 1985;162:11051110.

53 Goldschmidt TJ, Jansson L, Holmdahl R: In vivo elimination of $\mathrm{T}$ cells expressing specific $\mathrm{T}$-cell receptor V beta chains in mice susceptible to collagen-induced arthritis. Immunology 1990;69:508514.

54 Michaelsson E, Malmstrom V, Reis S, Engstrom A Burkhardt H, Holmdahl R: T cell recognition of carbohydrates on type II collagen. J Exp Med 1994; 180:745-749.

55 Corthay A, Backlund J, Broddefalk J, Michaelsson E, Goldschmidt TJ, Kihlberg J, Holmdahl R: Epitope glycosylation plays a critical role for $\mathrm{T}$ cell recognition of type II collagen in collagen-induced arthritis. Eur J Immunol 1998;28:2580-2590. 
56 Dzhambazov B, Holmdahl M, Yamada H, Lu S, Vestberg M, Holm B, Johnell O, Kihlberg J, Holmdahl R: The major T cell epitope on type II collagen is glycosylated in normal cartilage but modified by arthritis in both rats and humans. Eur J Immunol 2005;35:357-366.

57 Meezan E, Wu HC, Black PH, Robbins PW: Comparative studies on the carbohydrate-containing membrane components of normal and virus-transformed mouse fibroblasts. II. Separation of glycoproteins and glycopeptides by sephadex chromatography. Biochemistry 1969;8:2518-2524.

58 Dube DH, Bertozzi CR: Glycans in cancer and inflammation-potential for therapeutics and diagnostics. Nat Rev Drug Discov 2005;4:477-488.

59 Franco A: CTL-based cancer preventive/therapeutic vaccines for carcinomas: role of tumour-associated carbohydrate antigens. Scand J Immunol 2005; 61:391-397.

60 Cao Y, Stosiek P, Springer GF, Karsten U: Thomsen-Friedenreich-related carbohydrate antigens in normal adult human tissues: a systematic and comparative study. Histochem Cell Biol 1996;106: 197-207.

61 Slovin SF, Ragupathi G, Musselli C, Olkiewicz K, Verbel D, Kuduk SD, Schwarz JB, Sames D, Danishefsky S, Livingston PO, Scher HI: Fully synthetic carbohydrate-based vaccines in biochemically relapsed prostate cancer: clinical trial results with alpha-N-acetylgalactosamine-O-serine/threonine conjugate vaccine. J Clin Oncol 2003;21:4292-4298.

-62 Galli-Stampino L, Meinjohanns E, Frische K, Meldal M, Jensen T, Werdelin O, Mouritsen S: T-cell recognition of tumor-associated carbohydrates: the nature of the glycan moiety plays a decisive role in determining glycopeptide immunogenicity. Cancer Res 1997;57:3214-3222.

63 Gendler SJ, Spicer AP: Epithelial mucin genes. Annu Rev Physiol 1995;57:607-634.

64 Baldus SE, Hanisch FG: Biochemistry and pathological importance of mucin-associated antigens in gastrointestinal neoplasia. Adv Cancer Res 2000; 79:201-248.

65 Gad M, Jensen T, Gagne R, Komba S, Daugaard S, Kroman N, Meldal M, Werdelin O: MUC1-derived glycopeptide libraries with improved MHC anchors are strong antigens and prime mouse $\mathrm{T}$ cells for proliferative responses to lysates of human breast cancer tissue. Eur J Immunol 2003;33:1624-1632.

66 Zhao XJ, Cheung NK: GD2 oligosaccharide: target for cytotoxic T lymphocytes. J Exp Med 1995;182: 67-74.

67 Rudd PM, Elliott T, Cresswell P, Wilson IA, Dwek RA: Glycosylation and the immune system. Science 2001;291:2370-2376.

68 Malhotra R, Wormald MR, Rudd PM, Fischer PB, Dwek RA, Sim RB: Glycosylation changes of $\operatorname{IgG}$ associated with rheumatoid arthritis can activate complement via the mannose-binding protein. Nat Med 1995;1:237-243. 